\title{
Analysis of Islamic Education Existence in the National Education System in the Aspect of Education Funding Policy in Indonesia
}

\author{
Shobirin ${ }^{1}$, Fauzi ${ }^{2}$ \\ 1,2 Institut Agama Islam Negeri Purwokerto, Indonesia \\ showbirin@gmail.com,fauzi@iainpurwokerto.ac.id
}

\begin{abstract}
This article discusses the analysis of the existence of Islamic education in the national education system in the aspect of the education budget related to the study of Islamic education policies in Indonesian legislation. This study uses a qualitative approach with a qualitative descriptive type of research through a literature research study method. This encourages the need for the reconstruction of national education system policies in the budgetary aspect of educational institutions globally. This article analyzes that the existence of Islamic education in Indonesia in the national education system is a subsystem in national education, but it has not received the same attention as other education sectors. So this study criticizes the need for the reconstruction of national education system policy regulations on the aspects of the education budget in Indonesia and the solution to the existence of Islamic education in the national education system in the aspect of the education budget in Indonesia as an effort to reconstruct education policies in Indonesia offered by the author and input in the preparation. The education road map program in Indonesia by Commission X DPR RI on the direction of education development is the first, the concept of education equilibrium. The government issued a policy to equalize the education budget globally to end the dichotomy of education budget policies so far so that the existence of Islamic education is equal to the existence of other general education. Second, the separation between national education policies and political interests through the appointment of the minister of religion and the minister of the Ministry of Education and Culture-Research and Technology with professional figures is not based on entrusted elements from supborting parties/coalitions.
\end{abstract}

\section{Keywords}

Existence; Islamic education; education policy; national education system; Islamic education budget policy

\section{Introduction}

Islamic education is a formal educational institution organized by the Ministry of Religion and by community organizations/Islamic foundations with a characteristic form of Islamic schools/madrasas based on their respective institutional educational objectives. Education aims to educate citizens as individuals to bring overall development and make them productive citizens for the nation's future. (Sundaram, 2021, p. 127). The state guarantees the right of every citizen to obtain educational services, (Sujatmoko, 2010, p. 183) education belongs to the public and every citizen has the right to get the desired and proper education. (Arifah, 2018, p. 17). In reality, there are still many school-age citizens who cannot access education services that have been guaranteed by the state., many factors influence such as high education costs; difficult access to education; family economic background; etc. It is known that the budget allocation for Islamic education at the Ministry of Religion in 2020 is $55.88 \mathrm{~T}$ (Maryati, 2021a) and in 2021 it is $55.88 \mathrm{~T}$. (Ali, 2020) While it 
is also known that the Ministry of Education and Culture's education budget allocation for 2020 is $86.2 \mathrm{~T}$ (Maryati, 2021b) and in 2021 amounting to $81.53 \mathrm{~T}$. (A \& R, 2021) and, as well as at other ministries/institutions that also carry out educational functions.

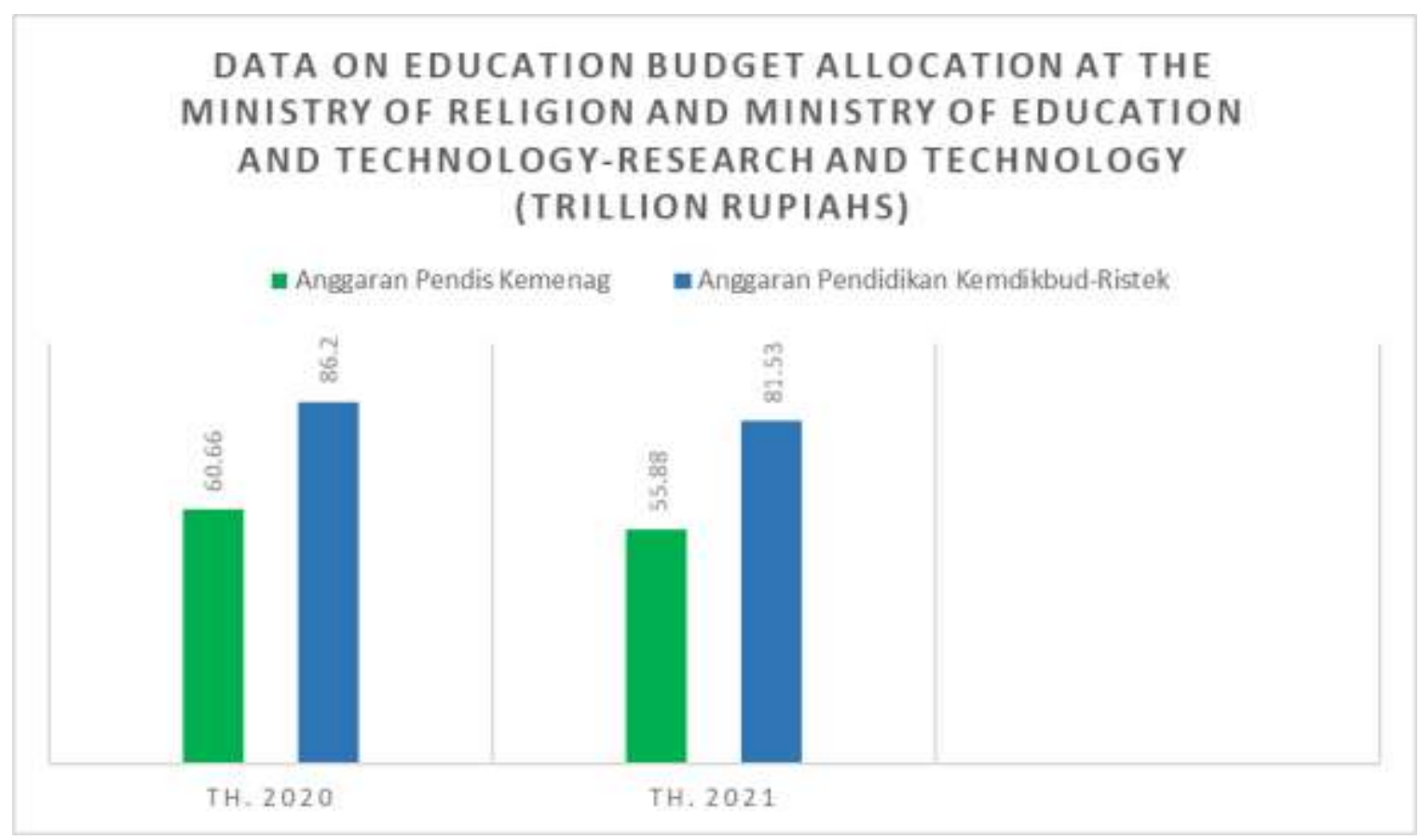

Education policy is part of public policy in the field of education. (Aini, 2017) Education policy is the key to achieving excellence and the country's existence in facing global competition, policy evaluation needs to be carried out (Arwildayanto et al., 2018, p. 92) so that education policy quality must get priority in policymaking. Education policy has a strategic role and must receive serious attention from policymakers at the central, regional, and related educational institutions. Education policy is an important thing that must be considered to become a standardized and directed system, there have been many educational policies approved by the government from the form of laws, government regulations, presidential regulations, ministerial regulations, ministerial decrees, and other policy products issued by agencies/institutions. Others, such as one of them is the national education system. (Luknanto, nd).

Public policy was action with intention determined by actor or several actors in overcoming a problem or task (Wu et al., 2017). Public policy was meant as state wisdom, a decision meant to overcome certain problem, to conduct certain activity, or to achieve certain activity, which was done by the authorized institution as part of implementation of state's task and development (Sulam et al., 2019).

The national education system in Indonesia has been regulated in several strategic policies, one of which is Law Number 20 of 2003. Law Number 2003 concerning the National Education System (Sisdiknas) contains 22 chapters and there are 77 articles. (Law Number 20 of 2003 concerning the National Education System RI, 2003) the policy regulates from the most basic to technical matters, such as general provisions; basis, function, and purpose; principles of education; the rights and obligations of citizens, parents, society, and the government; learners; path, level, and type of education; Language of instruction; compulsory education; national education standards; curriculum; educators and education personnel; educational facilities and infrastructure; education funding; education management; community participation in education; evaluation, accreditation, and 
certification; establishment of educational units; the provision of education by other state institutions; supervision; criminal provisions; transitional provisions; up to the closing provisions. The national education system is very complete and clear, but in reality, it has not been realized as mandated.

Education policy in Indonesia has been divided into two categories, namely Islamic education and general education, both of which are both long hands in matters of the intellectual life of the nation which is an obligation of the government to every citizen. (Arifah, 2018; Ismail, 2017; Mansir, 2019; Sundaram, 2021) However, in the part of the education budget policy provided by the state and enjoyed by students, public education managed by the Ministry of Education and Culture-Research and Technology is much higher than that in the Ministry. Religion is what is important to be studied about the analysis of the existence of Islamic education in the national education system in the aspect of education budget policy in Indonesia and input in the preparation/reflection of the road map program for education in Indonesia by Commission X DPR RI and as a direction in education development. This study is intended to be able to answer the formulation of the problem, how are the results of the analysis of the existence of Islamic education in the national education system in the aspect of education budget policy in Indonesia?

Akhiyat has studied the acceptability of the concept of integration of Islamic education in the national education system. The dichotomy of education in Indonesia has resulted in gaps between sources of knowledge, such as religion and general science. The integration of Islamic education in the national education system then becomes a problem, even though the state already has a policy as a legal umbrella, namely Law Number 20 of 2003 concerning the National Education System. So the results of this study conclude that the integration of Islamic education and general education can be carried out according to the current legal standing (Akhiyat, 2016).

Rubini conducted a study on the position of madrasas in the national education system (Sisdiknas). In this study, Rubini explained that the implications of Law Number 20 of 2003 concerning the National Education System for the Islamic education system, conceptually provide a strong foundation in developing and empowering Islamic education. The government's policy regarding the national education system is a breath of fresh air for Islamic education institutions, even more so for private institutions. This is because it is the government's strategic step in reforming the concept of education so far that has been running individually. The reform of the concept of the national education system into one stream has not yet been realized, this is because Islamic education is still managed by the Ministry of Religion. The results of this study recommend that global education arrangements be left to the Ministry of Education and Technology / Ministry of National Education, so that for the future the regulation of educational problems will be in one ministry/department unit only, unlike nowadays many departments manage both in-service and non-official education. respectively (Rubini, 2016).

M. Daud Yahya has studied the position of madrasas in the national education system in the era of regional autonomy. He explained that the madrasa journey was very long, even before Indonesia's independence madrasas existed. The existence of madrasas began to be recognized and official since Indonesia's independence and other general education institutions were also formed because they were considered to have different educational focuses. With the existence of the regional autonomy law and the law on the national education system, the existence of madrasas is increasingly cornered, this is because all education sectors are the affairs of the government, except madrasas and other official education which are under the auspices of their respective ministries/institutions. 
So the results of the analysis of this study are the limited budget for Islamic education, forcing educational institutions under the Ministry of Religion with limited budgets to be creative in managing and developing their madrasas.(Yahya, 2017)

Dainuri has conducted a study on the integration of Islamic education in the national education system. Dainuri explained that most Indonesian citizens are Muslim, of course, the government guarantees a quality Islamic education compared to general education. The role of education is very important in human life, it is not even replaced by anything in the process of human life. Education is an effort so that humans can develop their potential through a learning process or other means known to the community. UU no. 2003 concerning the National Education System emphasized that humans need education in their lives. The results of this study conclude that the national education system must be able to run optimally to achieve progress and national education goals.

K. Meenakshi Sundaram has reviewed the 1986 national education policy vs the 2020 national education policy. The aim of education is considered as a carrier for the development of the individual human being to be productive at present and the progress of the nation in the future. Each country certainly has its education system, based on the objectives of national education, social and cultural identity, economic progress, and state resilience. It is known that the education policy in India in 1986 the existing education system at that time was focused on a general curriculum framework that contained all things interrelated and flexible, a child-centered approach to education and basic education received more attention because it was considered the foundation for further education. Meanwhile, the 2020 era education policy in India emphasizes more on a holistic approach system to lead to a multidisciplinary education system according to the talents and interests of students.

Choirul Mahfud in his study of understanding political reform and Islamic education position in Indonesia explained that the political conditions that developed in Indonesia also influenced the existence of Islamic education. In the old order era Islamic education was independent and independent, during the New Order era with the existing policies in the Presidential Decree No. 2/1989 on the National Education System and was changed to the National Education System Law No. 20 of 2003 has placed Islamic education into a national education subsystem although the management has not changed according to the respective ministries. This study is more focused on discussing the implications of political reform on the position of Islamic education in Indonesia. (Mahfud, 2020) Based on many literature reviews above, it is known that there has been no previous study above that discusses the analysis of the existence of Islamic education in the national education system specifically examines the aspects of education budget policy in Indonesia.

\section{Research Methods}

This research is structured with a qualitative approach. The type of research in this study uses descriptive qualitative research in the study methodology. Where the activities carried out are in the form of connecting data with one another, then described as causal relations. The author relates various information data obtained regarding the existence of Islamic education in the national education system so far in the aspect of education budget policy in Indonesia by using the research study method in this study.

The method of study in this research is to use the literature research method. Where the author searches for related literature studies to be used as data which is then interpreted between one data and another. This literature research method is considered appropriate for analyzing the existence of Islamic education in the national education system in the aspect of education budget policy in Indonesia based on data/information obtained from existing data 
sources. The searches carried out by the author can be done from the publication of scientific papers in print and/or through certain digital search sites that are tailored to the required data sources.

Data sources are the origin of the initial data needed by researchers in a study/study. Sources of data in this article study come from publications of scientific papers that examine the existence of Islamic education in the national education system in the aspects of education budget policy in Indonesia. Some scientific publications obtained by the author are sourced from RPS recommendations for Islamic education courses in Indonesia, peer recommendations, and independent searches carried out by the author based on formulated data collection procedures.

The data collection procedure is a strategic step used by researchers in collecting the required data/information effectively and efficiently. The data collection procedure is carried out by tracking the publication of related scientific works. The author's tracking of the required data comes from independent book collections, national libraries, and digital search sites for scientific publications. The data obtained by the author then carried out data analysis with certain data analysis techniques.

The data analysis technique used a flow analysis model from Milles and Huberman. The data that has been collected is then processed through a reduction system based on the needs in this study. Furthermore, the results of the processed data are written descriptively in the research report. Data analysis goes hand in hand with critical report writing. So that more specifically the data analysis techniques used in this study are data reduction, data display, verification, and conclusion.

\section{Result and Discussion}

\subsection{The Existence of Islamic Education in the National Education System}

The existence of Islamic education in the national education system in Indonesia can be viewed from 2 different points of view, namely Islamic education in the field of study and Islamic education in the form of institutions/institutions. In the field of Islamic education studies, it focuses on education whose curriculum content is in the form of religious knowledge, such as the Al-Qur'an; morals; monotheism; fiqh; jurisprudence proposals; hadith; Arabic; and the history of Islamic culture. Meanwhile, general education focuses on curriculum content in the form of general sciences, such as mathematics; chemistry; technique; biology; geophysics; and so on. (Ismail, 2017, p. 66) The two domains of education between Islamic education and general education both lead to the achievement of national education goals (Taofik, 2020, p. 17) Although the sources of knowledge are different, however, These two domains play an equally important role in the achievement of national goals in Indonesia. The study of this article will sharpen the position of Islamic education in the policy of the national education system in the form of institutions/institutions to analyze its existence so far in the national education system.

The political journey in Indonesia always affects the education system. (Hartono, 2016; Ach. Syaiful, 2018; Suparlan \& Sutama, 2020) The birth of Law No. 20 of 2003 concerning the National Education System is part of the political journey in Indonesia. It is clearly stated in the policy of the national education system in Chapter XIII of Education Funding, part one, the responsibility for funding Article 46 paragraph (1) Education funding is the joint responsibility of the Government, Local Government, and the community. (2) The Government and Regional Governments are responsible for providing the education budget as stipulated in Article 31 paragraph (4) of the 1945 Constitution of the Republic of Indonesia 
(Law Number 20 of 2003 concerning the National Education System of the Republic of Indonesia, 2003).

Islamic education is part of the national education system which together with other general education can succeed and realize the goals of national education. Islamic education, general education, and service education that exist in other ministries/institutions are the responsibility of the state in providing funding to meet the needs of education implementation. already legal standing and it remains for the policymakers to carry out what is mandated in Law no. 20 of 2003 concerning the National Education System. When the current national education system policy regulations are deemed too weak to cover the interests of educational institutions globally by researchers, education practitioners, and the public, the government needs to reconstruct the regulations on renewable national education policies.

\subsection{Islamic Education Budget Policy in the National Education System}

Education budget policy is a policy aimed at facilitating the achievement of national development goals in the field of education. (H. Mansyur, 2012) Planning for education budget policies is not only contained in Law no. 20 of 2003 concerning the National Education System is also contained in the 1945 Constitution article 31 paragraph 4 "The state prioritizes the education budget of at least twenty percent of the state revenue and expenditure budget as well as from the regional income and expenditure budget to meet the needs of the implementation of national education." (Sujatmoko, 2010, pp. 183-184) However, the education budget policy planning has not yet been realized, ( $\mathrm{N} \&$ Arfeinia, 2020, p. 282) many factors influence such as dynamic political policies, policy implementers, distrust of school management. , up to the range for corruption. (Mansir, 2019, p. 130)

Regional autonomy policy in Law no. 32 of 2004, which has been going on for so long, has not been able to cover the budget for Islamic education. (Putera, 2010; Yahya, 2017) Factors that hinder the realization of regional autonomy policies to carry out the mandate of Law No. 20 of 2003 concerning the National Education System is that there are no derivative regulations that stipulate that local governments are obliged to allocate their budgets and other factors, namely because Islamic education is under the Ministry of Religion / Departments whose affairs go directly to the central government.

Islamic education budget policy is clear and is included in the part mandated by the national education system. The implementation of the budget policy should be implemented, there is no political influence on who or who is currently in power. (Hoddin, 2020) The imbalance in the amount of the budget for Islamic education as it is today should not occur, because every student in any educational institution has the same rights according to the mandate of the 1945 Constitution. (Sujatmoko, 2010) The problems that have occurred so far in the field are related to education budget policy regulations which have been previously stated in the chapter on education funding as rules that must be implemented by policymakers and have not yet been realized, can be used as wrong a strong factor for the reconstruction of the new national education system.

\subsection{Reconstruction of Islamic Education Budget Policy in the National Education System}

Political reform has always had a major impact on the change and sustainability of Islamic education in Indonesia, so Islamic education policymakers have begun to realize the importance of taking a role in changing political reform. (Mahfud, 2020, p. 136) Islamic education is a subsystem in national education that has the same role in achieving national education goals, so there is a need for efforts to be made by the government through 
equalizing Islamic education budget policies with general education and other education departments of the same type.

Equalizing education budget policies for each type of educational institution in Indonesia, whether public or private, should be implemented based on the mandate of Law No. 20 of 2003 concerning the National Education System. (Akhiyat, 2016; Hoddin, 2020) The education budget is something that is very much needed by every educational institution in providing education, every student needs completeness and infrastructure in learning. Teaching material books, learning media, teaching aids, learning areas, and the presence of the educator itself. It is not surprising that today, Islamic education institutions attract funding for the provision of education for the benefit of the educational process itself and the development of educational institutions even though the government has launched free education for students.

The free education program for all students in Indonesia will be realized when the education budget policy is implemented properly and this has never been realized until now. ( $\mathrm{N} \&$ Arfeinia, 2020) Education budget policy is an interest that should get priority in national education affairs. The benefits of education budget policies can be directly felt by all students and have implications for the future progress of the nation. Unlike today, the implementation of many state education institutions can eliminate the cost of education because all costs are borne by the government. Whereas Islamic education institutions, which both help government programs in realizing the goals of national education are not given the same budget, so every Islamic education institution must be creative in obtaining additional financing, management, and use of existing budgets. On the other hand, efforts to develop Islamic education independently by collecting financing from the community are hampered by the existence of policy regulations related to educational institutions that are prohibited from charging fees to the community. This phenomenon is an irony for practitioners of Islamic education in the field and calls for the reconstruction of budget policy regulations in the national education system in Indonesia, especially Islamic education.

\section{Discussion}

Islamic education grows and develops in Indonesia along with the entry of Islam into this country. From the time of the Islamic empire in Indonesia, the colonial period experienced by the Indonesian people, to the reformation period implemented in Indonesia, the implementation of Islamic education continues to experience significant growth and development. The implementation of Islamic education which initially can only be carried out in mosques, langgar, surau, Islamic boarding schools, colleges, or madrasas and students who attend Islamic education initially are students with middle to lower economic backgrounds, not priyai children whose parents work at Dutch offices, as well as education with a slum image by the community in the past. Now Islamic education has been transformed to rise and develop with promising quality education and superior programs respectively. The views and attractiveness of today's society also change the image of Islamic education. However, the public's positive view of the belief in education carried out by Islamic education institutions has not been followed by the views of the government.

The government's view of education in Indonesia is still focused on the provision of general education, which is a legacy of the education delivery model of the Dutch colonial government. This can be seen from the difference in education budget policies in Indonesia, between Islamic education managed by the Ministry of Religion (Kemenag) and general education managed by the Ministry of Education and Culture - Research and Technology (Kemendikbud-Research). When viewed from the point of view of the rights obtained by 
every Indonesian citizen in the field of education derived from the National Education System Law and the 1945 Constitution, of course, they all get the same rights whether they attend Islamic education institutions or in general education institutions. This kind of thing has not been able to be accommodated by policies and politics in Indonesia.

Education budget policy in Indonesia cannot be separated from political developments and developing policies. Changes in government regimes from year to year and changes in policymakers have contributed to the growth and development of Islamic education in Indonesia, this is because Islamic education is a subsystem in the delivery of national education for Indonesian citizens. The development of political policy always has an impact on various fields, such as education; finance; economy; investigation; and so forth. So the stakeholders of Islamic education currently realize the need to be involved in determining the direction of domestic politics so that Islamic education can still be considered.

Law No. 20 of 2003 concerning the National Education System is a product of the reform period for the sake of equitable distribution of national education and the achievement of long-lived national education goals with sub-optimal results. The National Education System mandates in Chapter XIII of Education Funding part one the responsibility for funding Article 46 paragraph (1) Education funding is the joint responsibility of the Government, Local Government, and the community. (2) The Government and Regional Governments are responsible for providing the education budget as stipulated in Article 31 paragraph (4) of the 1945 Constitution of the Republic of Indonesia. Legal standing regarding education budget policies has been clearly described above and there is no need for a budget policy dichotomy. education, especially between Islamic education and general education.

If it is restated explicitly what is contained in the Law on National Education System related to education funding is final and there is no need for debate. The government, local government, and the community have the responsibility for funding education with regulations that govern it. Education funding certainly includes whatever budget is needed to meet existing needs, be it Islamic education or general education. There are no priorities between them, but both have their respective functions and roles for the future of the nation. Things like this should be prioritized to formulate more appropriate policy regulations to accommodate all the interests of existing educational institutions and stand to help the government's task of achieving national education goals.

Implicitly what is contained in Law Number 20 of 2003 concerning the National Education System does not specifically mention Islamic education and general education. This lack of clarity has so far become anxious and the unwillingness of the local government to take responsibility for funding the Islamic education unit because there is no specific regulation regarding this matter and the local government has so far only wanted to realize education funding for general education under the auspices of the Ministry of Education and Culture. Research only. So, it is time for the government through its policymakers to open their eyes and hearts to formulate a new policy regulation concept with standard and directed rules and policy regulations that can accommodate all the interests of educational institutions, both public and madrasah / private schools.

Efforts to reconstruct education policies are deemed necessary to accommodate the existence of Islamic education in Indonesia based on the renewable national education system (Sisdiknas) policy regulations, especially related to the Islamic education budget. Two alternative solutions are tried to offer in this study of educational policy research: First, the concept of education equilibrium. The government through the relevant ministries/institutions can issue derivative regulations to strengthen the position of Islamic education in the national education system (Law No. 20 of 2003) through the policy of equalizing the national education budget. The existence of Islamic education must be recognized by the government 
and local governments. This recognition is not only in the form of legality in the form of operational permits and supervision by education supervisors alone but in the provision of an education budget following what the government has provided to general education units so far. Second, the separation between national education policies and policies of political interest. This can be done by appointing ministers at the Ministry of Religion and the Ministry of Education and Culture with professional people, not based on entrusted elements from supporting parties/election coalitions.

\section{Conclusion}

The existence of Islamic education in the national education system in the aspect of education budget policy in Indonesia is mandated to be the responsibility of the government, local governments, and the community in the element of education funding. In more detail, the responsibility for the education funding by the government and regional governments has been regulated in the proportion of the 1945 Indonesian Constitution. The reality is that so far there is still a dichotomy in education budget policy in Indonesia, on Islamic education and general education. The regional government believes that the implementation of Islamic education so far has not been their responsibility, this is because it has not been autonomous or has become a central authority. Meanwhile, the central government has assumed that the regional government has properly issued its budget policies on Islamic education and general education to meet the needs of providing education. So that with this situation the budget for Islamic education is very insufficient, to be sufficient for Islamic education institutions to sell their superior programs to get assistance from people who send their children to the institution in the form of infaq which is paid every month. On the other hand, efforts to develop such Islamic education are sometimes hampered by government regulations that prohibit the collection of such education fees. This is an irony in the field for implementers of Islamic education, so this is one of the bases for encouraging the implementation of the reconstruction of national education system policy regulations in the aspect of renewable education budget policies in Indonesia by accommodating educational institutions globally.

The results of the analysis of education policy studies on the existence of Islamic education in the national education system in the aspect of education budget policy in Indonesia are that it is deemed necessary to carry out the reconstruction of national education system policy regulations in the aspect of renewable education budget policies, as an effort to reconstruct and provide solutions to education policies in Indonesia. The author and input in the preparation of a road map program for education in Indonesia by Commission $\mathrm{X}$ of the DPR RI on the direction of education development are first, the concept of education equilibrium. The government issued a policy of equalizing the education budget in general by ending the dichotomy of education budget policies so far. Second, the separation between national education policies and political interests only through the appointment of ministers of religion and ministers at the Ministry of Education and Culture-Research and Technology with professional figures, not on entrusted elements from supporting parties/election coalitions.

This research has been attempted and carried out following scientific procedures, however, the results of this study still have limitations. Limitations in this study include: First, an analysis of the existence of Islamic education in the national education system in Indonesia, of course, has a very broad scope of discussion aspects based on various existing policy regulations, geographic location, human resources, educational unit systems, and others. . However, this study only focuses on the aspects of education budget policy in Indonesia. Second, the dichotomy of education budget policies in Indonesia so far certainly 
has other factors apart from the influence of policy regulations that are not yet global, broad elements/sectors of authority and institutional responsibility, the inability of policymakers to interpret national education system policies, and political interests.

\section{References}

A, D., \& R, A. (2021). Anggaran Kemendikbud Th 2020. Web Kemdikbud RI. https://www.kemdikbud.go.id/

Ach. Syaiful. (2018). Politik Pendidikan Islam Masa Reformasi. Jurnal Keislaman Dan Kemasyarakatan, 2(1).

Aini, R. (2017). Kebijakan Pendidikan. Kompasiana. https://www.kompasiana.com/rokyalaini/58d81fdeaf92737016d7ed70/kebijakanpendidikan

Akhiyat, A. (2016). Akseptabilitas Konsep Integrasi Pendidikan Islam dalam Sistem Pendidikan Nasional. Didaktika Religia, https://doi.org/10.30762/didaktika.v4.i2.p39-59.2016

Ali, N. (2020). Anggaran Pendis Kemenag Th 2020. Web Pendis Kemenag. https://kemenag.go.id/

Arifah, U. (2018). Kebijakan Publik Dalam Anggaran Pendidikan. Cakrawala: Jurnal Manajemen Pendidikan ..., 2(1).

Arwildayanto, Suking, A., \& Sumar, W. T. (2018). Analisis Kebijakan Pendidikan. In E. Kuswandi (Ed.), Lentera: Indonesian Journal of Multidisciplinary Islamic Studies (Pertama, Vol. 1). CV CENDEKIA PRESS. https://doi.org/10.32505/lentera.v1i1.1662

H. Mansyur, M. (2012). Oleh : Masykur H Mansyur Disampaikan pada kegiatan Workshop Guru Pasca Sertifikasi untuk membentuk Guru yang Profesional di Lingkungan Kementerian Agama Kabupaten Karawang Senin , 14 Mei 2012 bertempat di Hotel Permata Ruby Karawang. Solusi, 10(22), 1-8.

Hartono, Y. (2016). Pendidikan Dan Kebijakan Politik (Kajian Reformasi Pendidikan Di Indonesia Masa Orde Lama Hingga Reformasi). AGASTYA: JURNAL SEJARAH DAN PEMBELAJARANNYA, 6(01). https://doi.org/10.25273/ajsp.v6i01.879

Hoddin, M. S. (2020). Dinamika Politik Pendidikan Islam Di Indonesia; Studi Kebijakan Pendidikan Islam Pada Masa Pra-Kemerdekaan hingga Reformasi. Jurnal Ilmiah Iqra', 14(1). https://doi.org/10.30984/jii.v14i1.1035

Ismail, F. (2017). Paradigma Pendidikan Islam (P. Latifah (Ed.); I). PT Remaja Rosdakarya.

Luknanto, D. (n.d.). Kumpulan Peraturan Terkait Pendidikan Dasar dan Menengah di Internet. https://luk.staff.ugm.ac.id/atur/bsnp/

Mahfud, C. (2020). Understanding Political Reform and Islamic Education Position in Indonesia. AL-MURABBI: Jurnal Studi Kependidikan Dan Keislaman 6 (2), 130-136, 6(2).

https://doi.org/http://ejournal.kopertais4.or.id/mataraman/index.php/murabbi/article/vie w/3768

Mansir, F. (2019). Political Policy Analysis of the National Education Budget In Islamic Education Studies. Istawa: Jurnal Pendidikan Islam, 4(2), 114-131. https://doi.org/10.24269/ijpi.v4i2.1992

Maryati. (2021a). Realisasi Anggaran Kemenag Tahun 2020. Antara News. https://m.antaranews.com/berita/1953324/realisasi-anggaran-kemenag-tahun-2020capai-9607-persen

Maryati. (2021b). Realisasi Anggaran Kemendikbud tahun 2020. Antara News. https://m.antaranews.com/berita/1957192/realisasi-anggaran-kemendikbud-tahun-2020capai-91-persen 
N, A. M., \& Arfeinia, R. (2020). KEBIJAKAN PEMERINTAH TERHADAP PENDIDIKAN ISLAM. Andragogi: Jurnal Pendidikan Islam Dan Manajemen Pendidikan Islam, 2(2). https://doi.org/10.36671/andragogi.v2i2.105

Putera, R. E. (2010). Formulasi Kebijakan Anggaran Pendidikan dalam Mewujudkan Peningkatan Pemerataan Pendidikan Era Otonomi Daerah di Kabupaten Solok. Jurnal Demokrasi, 9(Nomor 2), 205-226.

Rubini. (2016). Kedudukan Madrasah Dalam Sistem Pendidikan Nasional (Sisdiknas). Journal Al-Manar, 5(1).

Sujatmoko, E. (2010). Hak Warga Negara Dalam Memperoleh Pendidikan. Jurnal Konstitusi, 7(1), 181-212.

Sulam, K., Syakur, A., and Musyarofah, L. (2019). The Implementation of 21St Century Skills As The New Learning Paradigm to The Result Of Student's Career And Life Skills. Magister Scientiae 2, 228-237.

Sundaram, K. M. (2021). National Education Policy 1986 Vs National Education Policy 2020 - A Comparative Study. International Research Journal on Advanced Science Hub, 2(Special Issue ICAMET 10S), 127-131. https://doi.org/10.47392/irjash.2020.210

Suparlan, \& Sutama. (2020). ARAH POLITIK PENDIDIKAN ISLAM DI MASA DISRUPSI. Paedagoria : Jurnal Kajian, Penelitian Dan Pengembangan Kependidikan, 11(3).

Taofik, A. (2020). Lembaga Pendidikan Islam di Indonesia. Indonesian Journal Of Adult and Community Education, 20(2), 17-34. https://ejournal.upi.edu/index.php/IJACE/article/view/30874

Undang-Undang Nomor 20 Tahun 2003 Tentang Sistem Pendidikan Nasional RI. (2003). Pusdiklat.Perpusnas.Go.Id.

https://pusdiklat.perpusnas.go.id/public/media/regulasi/2019/11/12/2019_11_1203_49_06_9ab7e1fa524ba603bc2cdbeb7bff93c3.pdf

Yahya, M. D. (2017). Posisi Madrasah dalam Sistem Pendidikan Nasional di Era Otonomi Daerah. Khazanah: Jurnal Studi Islam Dan Humaniora, 12(1). https://doi.org/10.18592/khazanah.v12i1.303 